\title{
Radium Ra 224-labeled Calcium Carbonate Microparticles
}

National Cancer Institute

\section{Source}

National Cancer Institute. Radium Ra 224-labeled Calcium Carbonate Microparticles. NCI

Thesaurus. Code C159537.

A radiopharmaceutical composed of biodegradable calcium carbonate microspheres labeled with the alpha-emitting radioisotope radium Ra 224, with antineoplastic activity. Upon intraperitoneal (IP) administration of the radium Ra 224-labeled calcium carbonate microparticles, Ra 224 kills tumor cells through local emission of high energy alpha particles, causing DNA double-strand breaks. The short range effects of alpha emission allows for localized DNA damage with limited toxicity to nearby healthy tissue. 